1776, that was felt with some intensity (about 6, Rossi-Forel scale) at Canterbury, Sandwich, Deal, Dover, Folkestone and Ashford, and, though very slightly, at Calais, thirty-four miles from the centre.

\section{Sands, Clays and Minerals}

THE most recent issue of this journal (3, No. 1, November 1936. A. L. Curtis, Westmoor Laboratory, P.O. Box 61, Chatteris, Cambridgeshire, price $3 s .6 d$.) has been considerably enlarged and contains articles covering a wide range of subjects. Topies of economic importance dealt with in this number include nickel, silica sand as a basis for phosphate deficiency tests on lettuce, minerals of Brazil, titanium oxide in industry, boron, soils, industrial water supply, barytes in Greece, mining resources in Tanganyika, etc. The articles are written by authors actually engaged in research on the subject, thus making them authoritative. A contribution by A. L. Curtis on the history and activities of the Fuel Research Station at Greenwich makes interesting reading. The journal is attractively produced, and is an excellent source of information, especially for mineralogists, chemical engineers and other men of science and technology concerned particularly with the mineral resources of the British Empire.

\section{Physical Society's Exhibition Catalogue}

THe Catalogue of this Exhibition, which was open on January 5-7, now covers nearly 200 pages and is well provided with indexes of exhibitors and of apparatus, plans, stall numbers on the outer top corner of each page, marks for new apparatus and for demonstrations, all of which help a visitor to find readily what he wants particularly to see. Illustrations are plentiful, but many are limited to views of the outsides of the boxes containing the instruments, while the interest of the visitor is more often centred in the principle of the instrument itself. The division of the catalogue into two sections devoted respectively to trade exhibits and research and educational exhibits is maintained, and the award of prizes to apprentices for exhibits of work done is continued. A new announcement is made of the intention of the Council to apply part of the legacy bequeathed to the Society by the late Herbert Spencer, for grants to fellows for the purchase of special research apparatus. The order of the stands in the catalogue and their stand numbers are arranged geographically to facilitate reference, and the asterisk which now marks a new exhibit in the body of the eatalogue might with advantage in future years appear also in the apparatus index.

\section{Announcements}

Str WILITAM BragG will open the new extension to the Research Laboratories of the British Association of Research for the Cocoa, Chocolate, Sugar Confectionery and Jam Trades and the British Food Manufacturers' Research Association at 2 and 4, Dalmeny Avenue, Holloway, London, N.7, on January 19. There will be a reception from 3 until 6 p.m.
THE King has been pleased, on the recommendation of the Secretary of State for Scotland, to approve the appointment of Prof. Lancelot Hogben, professor of social biology in the University of London, to be regius professor of natural history in the University of Aberdeen, in succession to Prof. James Ritchie. Prof. Hogben was formerly assistant professor of zoology in McGill University, Montreal, and professor of zoology in the University of Cape Town.

Mr. N. B. KInNEAR and Dr. H. A. Baylis have been appointed to deputy keeperships in the Department of Zoology of the British Museum (Natural History). Mr. Kinnear was born in 1882 and is a great-grandson of Sir William Jardine, the early nineteenth century naturalist. $\mathrm{He}_{\mathrm{e}}$ is well known as an ornithologist, and prior to his appointment to the Museum sixteen years ago was in charge of the Bombay Natural History Society's Museum. He is the editor of the Bulletin of the British Ornithologists' Club. Dr. Baylis was born in 1889 and was educated at Epsom College and Jesus College, Oxford. $\mathrm{He}$ entered the Museum in 1912, and has specialized throughout his eareer in parasitic worms. $\mathrm{He}_{\theta}$ is the author of many scientific papers on this subject, and has built up a very large collection of these organisms, of which, before his time, the Museum possessed only a few specimens.

Prof. P. M. S. BLAcketr will deliver the Cantor Lectures before the Royal Society of Arts on January 18, 25 and February 1. The subject of the lectures will be "Cosmic Rays".

The Sir Halley Stewart Trust has placed at the disposal of the Medical Research Council a sum of $£ 500$ a year for three years for a senior fellowship tenable in the Neurological Research Unit at the National Hospital for Nervous Diseases, Queen Square, London. This arrangement has been gratefully accepted by the Council with the concurrence of the Medical Committee of the Hospital, and the position has been awarded to Dr. Joseph Doupe.

THE seventy-first volume of the Journal of Anatomy is termed the "Elliot Smith Volume" and is dedicated to Sir Grafton Elliot Smith (see p. 57). Appropriately enough, Part 1, which was issued last October, contains his portrait as a frontispiece and commences with a biographical sketch of his early career by Prof. J. T. Wilson, who, in his early years in the Challis chair of anatomy in the University of Sydney, included Elliot Smith among his students.

MR. B. D. W. Morrey, of "Holy Trinity Vicarage, Madeira Road, Bournemouth, Hants, asks anyone who has been studying, or has at any time studied, communication among ants, to get in touch with him.

Wrul Mr. Paul Molde, of Copenhagen, who sent a communication to the Editor entitled "On the Atomic Structure of Living Matter : A Biole Hypothesis", kindly communicate his address. 